In this issue:

ACRL New England Chapter

Conference

Current Comments, by H. William Axford

Inside Washington

Schedule of Midwinter Meetings

News From the Field

Report to the ACRL Membership

People

Classified Advertising

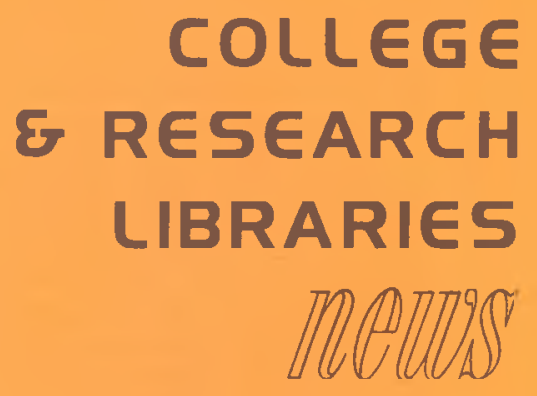

NO. 1 - JANUARY 1975

News Issue (A) of College \& Research Libraries, vol. 36, no. I

\title{
New England Chapter of ACRL Meets
}

Editor's note: Although there is an abundance of meetings, conferences, seminars, and workshops held each year of interest to academic librarians, there is a dearth of reporting in the literature of the exchanges of information and ideas that transpire at these gatherings. The following is a report, submitted at the editor's request by Anne Roberts, assistant librarian, State University of New York at Albany, of a recent conference. The editor invites further submissions of reports on meetings for consideration for inclusion in the News. These should be addressed to the editor of the News. While we intend to continue to announce upcoming meetings, it is the hope of the editor that the proceedings will also be reported informally in the News.

The ACRL New England Chapter Conference on Bibliographic Instruction, held at the modern Gutman Library of the Harvard Graduate School of Education on Friday, November 15,1974 , drew over 280 librarians from the northeastern states, New York, Tennessee, Virginia, and Texas. The steering committee of the chapter suggested the idea of a workshop on bibliographic instruction last spring, and the planning committee, headed by Irma Y. Johnson, designed a program to try to fit the needs of both librarians and institutions. As both the numbers of attendees and varieties of topics illustrate, bibliographic instruction is of real concern to academic librarians. The morning session began with a display of materials in a "Bibliographic Instruction Fair," including exhibits of various media used such as printed subject guides, handbooks, bibliographies, workbooks, slide-tapes, films, and videotapes.

The three keynote speakers were familiar names to those involved in library orientation and instruction. Thomas Kirk, science librarian at Earlham College, Richmond, Indiana, and chairperson of the ACRL Committee on Bibliographic Instruction, spoke on "Definitions; Objectives; and Evaluation." He defined biblio-

(Continued on page 5)

Associate

News

Editor

Named

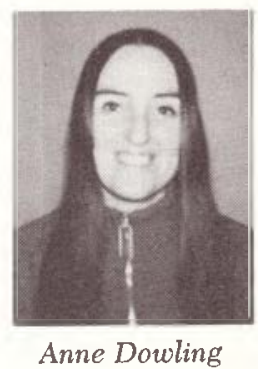

Anne Dowling, assistant librarian at the State University of New York at Albany, has been named Associate Editor, College \& Research Libraries News. Ms. Dowling received an MLS degree from SUNY at Albany in 1971. She has served in the Serials and Cataloging departments and is currently the assistant librarian in the Acquisitions Department at Albany. 


\section{New England (Continued from p. 1)}

graphic instruction as differing from orientation, although usually given in conjunction with it; as the organization of material and how to get at it, rather than physical organization of facilities. Kirk cited the ACRL Bibliographic Instruction Task Force "Model Statement of Objectives" as a useful tool to use in a program (1) to know what you are doing both in shortterm and long-term circumstances; (2) to know whether or not you have been successful; and (3) to tell others what you are doing. $\mathrm{He}$ stressed that objectives must be adapted to each institution's needs and circumstances and constantly need modification as the situation changes.

Sharon Lossing, reference librarian, University of Michigan, and bibliographic instructor, addressed herself to the topic "Critical Questions in Administration of Programs," which she felt came into three problem categories: (1) problems within the unit; (2) problems within the library; and (3) problems between the library and the library community. She noted the departmental problems which arise when a reference librarian begins to do formal teaching; the flexibility of the staff goes down and the resentment goes up. The burdens placed on one person doing bibliographic instruction are awesome since that person becomes the resource person for all the students the librarian teaches and often becomes fatigued and exhausted. Lossing felt that it was better to have several librarians doing bibliographic instruction, to share the responsibility. She emphasized that imagination and creativity were more important than subject specialties in a successful bibliographic instruction program. As for problems within the library, she

\section{Name CURL Assistant Editor}

Elaine L. Downing has been appointed Assistant Editor, College \& Research Libraries, effective with the January 1975 issue. Miss Downing is a graduate of the State University of New York at Buffalo and received her graduate degree in librarianship from the School of Library and Information Science at the College of Arts and Science, State University of New York, Geneseo. Miss Downing has been a librarian at the State University College, Oneonta, New York, since 1970 and presently serves as assistant head, Acquisitions Department. advocated flexibility among departments, with the possibility of crossing roles between technical service and public service librarians. A liaison person was deemed necessary to coordinate the program and to anticipate potential growth within both the institution and the profession. The problems between the library and the library community were seen as ones of growth, both in quality and quantity of reference services, and in public relations; as the program grows and is successful, the demand for more bibliographic instruction increases.

Carla J. Stoffle, head of Public Services Division, University of Wisconsin-Parkside, and chairperson of the Wisconsin Task Force on Instruction in Academic Libraries, spoke on "Review of Modes of Instruction; And A Look Ahead." She emphasized that the modes, or types, of instruction depend on the library and its resources and the audience. She then outlined the advantages and disadvantages of six modes: the formal course; course-integrated instruction; tutorials, seminars, and minicourses; print and tape/print; slides and slide-tapes; and videotapes. Stoffle urged librarians to develop their own materials and share them cooperatively; she stated that the library profession must develop networks, teaching techniques, workshops, and kits for bibliographic instruction. She cited the Wisconsin program as an example of a state system which is developing a program for library orientation and instruction. Stoffle pointed out that librarians must document their successes and failures carefully with conrete examples. In her opinion practicing librarians should pressure library schools to provide for bibliographic instruction teaching techniques in the curriculum, with expert library faculty to teach them. A brief discussion period followed during which questions from the audience were answered.

The six separate afternoon sessions were devoted to examining one of the modes mentioned in the morning meeting. Each session was offered twice so that librarians could attend whichever ones interested them. "Tutorials/ Seminars/Minicourses" consisted of a panel of three librarians describing their experiences. Heather E. Cole, reference librarian, Widener Library, Harvard University, described the tutorial method used by the four reference librarians to interview beginning graduate students and to introduce them to the important bibliographic tools for their appropriate subject fields and how to use them. The librarians arrange interviews by appointment after contact. ing the departments; these interviews are largely geared to the individual's needs and are often a time for the student to relax and express concern about not knowing how to approach library materials. Cole pointed out the need to guide the students logically and not to over- 
whelm them with too much information.

Marie Lannon, reference librarian, Gutman Library, Harvard Graduate School of Education, told about conducting individualized interviews at the computer terminal where the librarian must get enough information from the user to formulate the strategy needed for an effective bibliographic search. The problems here involve bibliographic instruction in the user's subject field as well as in data-base retrieval of information.

Paula Mark, instructional services librarian, University of Massachusetts, spoke on the question of which program one should use for undergraduates or graduates, and whether or not the program should present the users' needs or the librarians' strengths. A reference department subcommittee was formed at her library which planned a minicourse based on responses from students by way of a questionnaire. The course covered (1) the general use of library materials; (2) how to locate them (interlibraryloan verification procedure was stressed); (3) a general session on the social sciences; and (4) a general session on humanities and sciences. This minicourse, based on user needs, was cooperatively taught by members of the reference department. Another approach mentioned that used librarians' skills was having a kit available for each subject, including the appropriate research guide and index tools. Students could then take the entire series offered or only those which they need.

The conference concluded with sherry at the end of the afternoon, allowing time to renew old contacts and make new ones. Librarians returned home to their libraries with the renewed stimulation and enthusiasms that these library orientation and instruction conferences generate.

\section{Schedule of Midwinter Meetings}

Midwinter Meeting

Chicago, Illinois

JANUARY 19-25, 1975

\section{ACRL Boand OF Directons}

Monday, January 20, 10:00 a.m.-12:00 noon Thursday, January 23, 2:00-6:00 p.m.

\section{ACRL Divisional Committees}

\section{Academic Status}

Monday, January 20, 2:00-4:00 p.m.

Tuesday, January 21, 2:00-4:00 p.m.

Wednesday, January 22, 10:00 a.m.-12:00 noon

Academic Status Preconference Planning

Sunday, January 19, 2:00-6:00 p.m.

Appointments and Nominations

Sunday, January 19, 2:00-4:00 p.m. (Closed)

Monday, January 20, 8:30-10:30 p.m. (Closed)

Tuesday, January $21, \quad 8: 30-10: 30 \quad$ p.m. (Closed)

Thursday, January 23, 10:00 a.m.-12:00 noon (Closed)

\section{Audiovisual}

Monday, January 20, 4:30-6:00 p.m.

Wednesday, January 22, 8:00-9:30 a.m.

\section{Bibliographic Instruction}

Sunday, January 19, 8:30-10:30 p.m.

Tuesday, January 21, 8:00-9:30 a.m.

\section{Chapter Development}

Monday, January 20, 8:00-9:30 a.m.

Tuesday, January 21, 8:00-9:30 a.m.
Community Use of Academic Libraries

Tuesday, January 21, 8:00-9:30 a.m.

Thursday, January 23, 8:00-9:30 a.m.

Conference Program Planning-San Francisco

Tuesday, January 21, 8:30-10:30 p.m.

Conference Program Planning-Chicago

Monday, January 20, 2:00-4:00 p.m.

Constitution and Bylaws

Sunday, January 19, 8:30-10:30 p.m.

Monday, January 20, 8:00-9:30 a.m.

Thursday, January 23, 8:00-9:30 a.m.

Cooperation with Educational and Professional

Organizations

Wednesday, January 22, 10:00 a.m.-12:00 noon

Interlibrary Communications and Information

Networks

Monday, January 20, 8:00-9:30 a.m.

Internship

Sunday, January 19, 5:00-7:30 p.m.

Legislation

Monday, January 20, 2:00-4:00 p.m.

Wednesday, January 22, 12:00 noon-2:00 p.m.

Planning

Tuesday, January 21, 2:00-4:00 p.m.

Subcommittee on Goals, Priorities, and

Structures

Monday, January 20, 2:00-4:00 p.m.

Tuesday, January 21, 2:00-4:00 p.m.

Wednesday, January 22, 10:00 a.m.-12:00 noon 